Engineer Research and

Development Center

Engineer Site Identification for the Tactical Environment (ENSITE)

\title{
Parameters Used in the Tactical Airfield Siting Selection Module for ENSITE
}

Joseph A. Gamez, Patrick J. Guertin, Eric L. Kreiger, and

September 2018

George W. Calfas

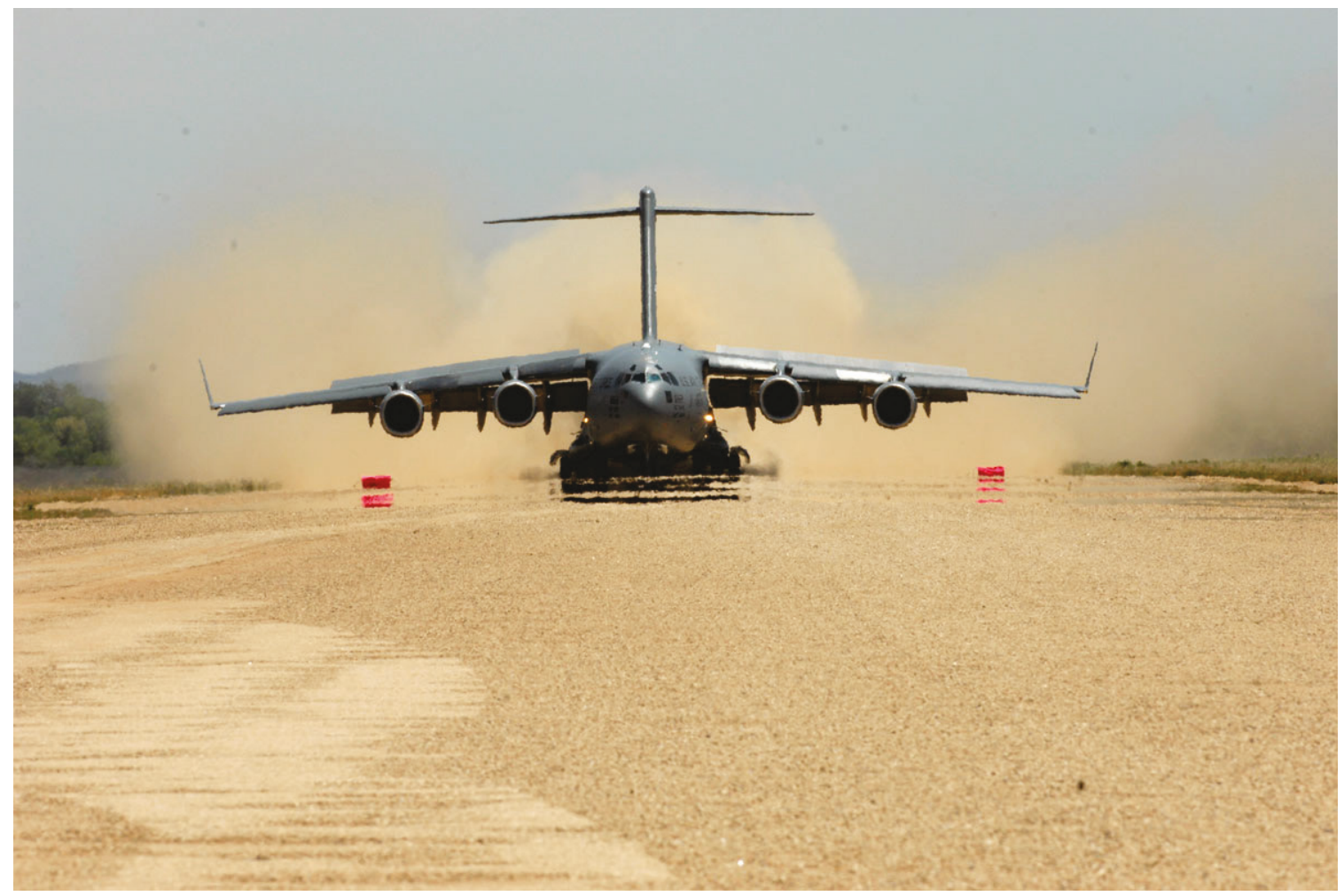


The U.S. Army Engineer Research and Development Center (ERDC) solves the nation's toughest engineering and environmental challenges. ERDC develops innovative solutions in civil and military engineering, geospatial sciences, water resources, and environmental sciences for the Army, the Department of Defense, civilian agencies, and our nation's public good. Find out more at www.erdc.usace.army.mil.

To search for other technical reports published by ERDC, visit the ERDC online library at http://acwc.sdp.sirsi.net/client/default. 


\section{Parameters Used in the Tactical Airfield Siting Selection Module for ENSITE}

Joseph A. Gamez, Patrick J. Guertin, Eric L. Kreiger, and George W. Calfas

U.S. Army Engineer Research and Development Center (ERDC)

Construction Engineering and ResearchLaboratory (CERL)

2902 Newmark

Champaign,IL 61822

Final Report

Approved for public release; distribution is unlimited.

Prepared for Assistant Secretary of the Army for Acquisition, Logistics and Technology (ASA(ALT) 103 Army Pentagon

Washington, DC 20314-1000

Under Project \#45509, “Military Facilities Engineering Technology” 


\section{Abstract}

The Army must have an ability to rapidly plan and locate engineering sites, such as soldier base camps or airfields, for supporting maximum combat effectiveness of deployed forces. By defining mission-specific site requirements prior to force deployment and facility locations and construction, Army commanders and planners are able to optimize various siting and design decisions. This report documents the technical and doctrinal parameters used to develop the Tactical Airport Site Selection (TASS) module in the Engineer Site Identification for the Tactical Environment (ENSITE) computer planning tool. ENSITE/TASS is a remote planning tool designed for field-expedient use and a very specific set of design criteria. This report contains the rationale for why the ENSITE/TASS development process made certain assumptions, how it calculated certain quantities, and which sources of data it incorporated. 


\section{Contents}

Abstract.................................................................................................................................. if

Figures and Tables......................................................................................................................

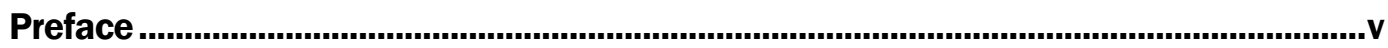

Unit Conversion Factors..................................................................................................vi

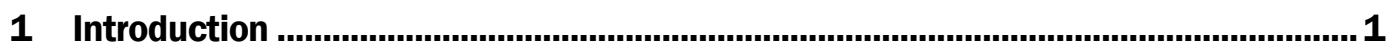

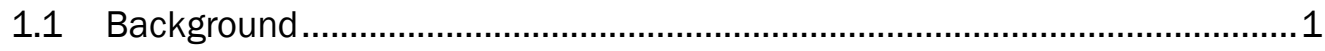

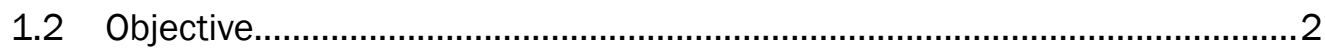

1.3 Methodology ..............................................................................

2 Technical Parameters and Specifications .............................................................. 3

2.1 Expedient airfield design overview .............................................................

2.2 Select the runway location .................................................................. 4

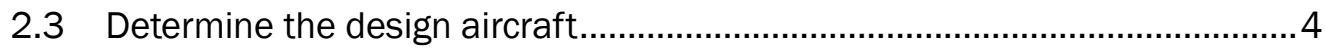

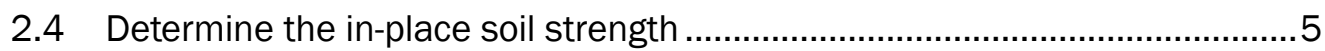

2.4.1 Discussion on the relationship between USCS soil type and CBR ........................ 7

2.5 Determine the required number of passes................................................ 8

2.6 Determine the allowable number of passes and surface type...................... 8

2.7 Determine the runway length and width .................................................

2.7.1 Runway length design example. .................................................................... 11

2.7.2 Determine approach zones and imaginary surfaces ......................................... 14

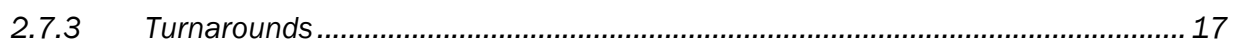

2.8 Determine the runway orientation .......................................................... 18

2.8.1 Discussion and further guidance on the $13 \mathrm{mph}$ beam wind criterion ................ 19

2.8.2 Runway orientation example............................................................................. 19

2.8.3 True north vs. magnetic north ........................................................................ 21

2.9 Design components excluded from consideration ................................... 22

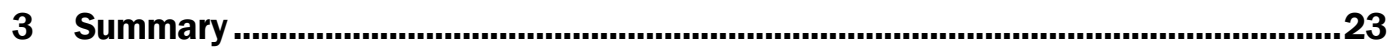

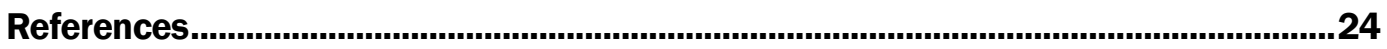

\section{Report Documentation Page}




\section{Figures and Tables}

\section{Figures}

Figure 1. Plot correlating passes and CBR (modified from TM 3-34.48-2 [2016]),

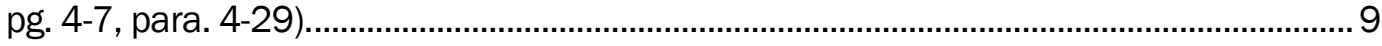

Figure 2. Isopleths of pressure altitude (from TM 3-34.48-2 [2016], p. 2-11)..................13

Figure 3. Isopleths of average maximum temperature (from TM 3-34.48-2

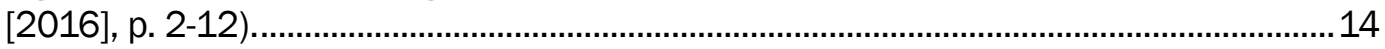

Figure 4. Runway end detail in plan view (from ETL 09-6 [2009], Atch. 1, pg. 1). ............16

Figure 5. Runway end detail in profile view (from ETL 09-6 [2009], Atch. 1, pg. 1)..........16

Figure 6. Runway end details in plan view showing the accident-potential zone (from ETL 09-6 [2009], Atch. 1, pg. 2).

Figure 7. Schematic diagram of a turnaround (after ETL 09-6 [2009], Atch. 1, pg. 3)

Figure 8. Wind vector example (ERDC-CERL).............................................................20

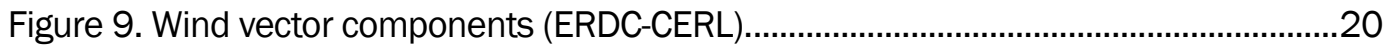

Figure 10. Determination of runway orientation (ERDC-CERL............................................21

\section{Tables}

Table 1. Design aircraft gross weight for use in expedient runway design (modified from FM 5-430-00-2 [1994]).

Table 2. Unified Soil Classification System (modified from ETL 97-9 1997, Atch.

1, pg. 44, para. A.1).

Table 3. Estimated CBR values for USCS classified soils (modified after ARA, Inc.-

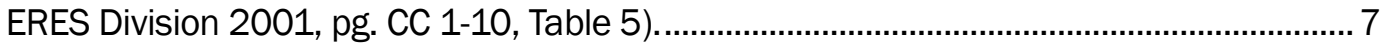

Table 4. Characteristics of soil groups pertaining to roads and airfields (modified from TM 3-34.43 [2015]).................................................................................................. 8

Table 5. Airfield design components eliminated from consideration in TASS.....................22 


\section{Preface}

This study was conducted for Assistant Secretary of the Army for Acquisition, Logistics and Technology (ASA(ALT)) under T45, "Military Facilities Engineering Technology" and Project Number 455009, "Contingency Base Site Identification Tool for the Tactical Environment." The technical monitor was Mr. Kurt Kinnevan, CEERD-CZT.

The work was performed under supervision of the Environmental Processes Branch (CNE) of the Installation Division (CN), U.S. Army Engineer Research and Development Center, Construction Engineering Research Laboratory (ERDC-CERL). At the time of publication, Mr. H. Garth Anderson was Chief, CEERD-CNE; Ms. Michelle Hanson was Chief, CEERD-CN; and Mr. Kurt Kinnevan, CEERD-CZT was the Technical Director for Infrastructure for Combat Operations. The Deputy Director of ERDC-CERL was Dr. Kirankumar Topudurti and the Director was Dr. Lance D. Hansen.

COL Ivan P. Beckman was Commander of ERDC, and Dr. David W. Pittman was the Director. 


\section{Unit Conversion Factors}

\begin{tabular}{|l|l|l|}
\hline Multiply & By & To Obtain \\
\hline degrees (angle) & 0.01745329 & radians \\
\hline degrees Fahrenheit & $(\mathrm{F}-32) / 1.8$ & degrees Celsius \\
\hline feet & 0.3048 & meters \\
\hline inches & 0.0254 & meters \\
\hline miles per hour & 0.44704 & meters per second \\
\hline pounds (force) (Kip = 1,000 pounds force) & 4.448222 & newtons \\
\hline pounds (mass) per cubic foot & 16.01846 & kilograms per cubic meter \\
\hline pounds (mass) per cubic inch & $2.757990 \mathrm{E}+04$ & kilograms per cubic meter \\
\hline
\end{tabular}




\section{Introduction}

\subsection{Background}

The U.S. Army must have an ability to rapidly plan and locate engineered sites, such as soldier base camps or airfields, for supporting maximum combat effectiveness of deployed forces. By defining mission-specific site requirements prior to force deployment and facility locations and construction, Army commanders and planners are able to optimize various siting and design decisions.

This report documents the technical and doctrinal parameters used to develop the Tactical Airport Site Selection (TASS) module in the Engineer Site Identification for the Tactical Environmnt (ENSITE) computer planning tool. The overall ENSITE program is dedicated to empowering military planners with the data and knowledge for in-theater construction locations. ENSITE is a computer program that is comprised of various integrated capabilities for siting military construction and infrastructure.

First developed at the Engineer Research and Development Center-Geotechnical Structure Laboratory (ERDC-GSL), TASS is a geographic information systems (GIS)-based methodology for sighting airfields in theater (Anderton et al. 2007). The original TASS methodology included airfield site selection parameters for both existing and improvised airfields. These selection parameters, however, included only site location and runway orientation that were based on local terrain features.

While the recently updated and combined ENSITE/TASS version limits its scope to expedient runways, ${ }^{1}$ it includes an expanded set of engineeringbased selection parameters. TASS is also now embedded within the ENSITE environment, which enhances applicability because ENSITE incorporates TASS into a system and tool that are designed for field-expedient use. TASS is also coupled with ENSITE's other supporting applications, such as its Climate Means and Engineering Report analysis tools.

\footnotetext{
1 This document defines expedient runways as improvised expedient runways; it does not consider taxiways, shelters, and/or other structures associated with airfield design.
} 


\subsection{Objective}

This report defines the technical and doctrine-derived parameters used to construct the TASS module within the ENSITE planning tool.

\subsection{Methodology}

Methods used in this report consisted of Department of Defense (DoD) doctrine review, consultations with the original authors of the TASS application, and consultations with airfield design experts in the DoD.

The process of expedient runway design is driven by the following factors: (1) type of aircraft, (2) local climate, (3) prevailing winds, and (4) topography. ENSITE/TASS uses those same design factors, specifically as prescribed in military design manuals such as Training Manual (TM) 3-34.482 (2016), Field Manual (FM) 5-430-00-2 (1994), Unified Facilities Criteria (UFC) 3-260-02 (2001), and Engineer Technical Letter (ETL) 09-6 (2009). Thus, ENSITE/TASS designs for a very specific set of circumstances in a very specific way. This document describes that process so the ENSITE/TASS user can understand the design methodology. Specifics are provided via technical parameters and specifications that are detailed in Chapter 2. 


\section{Technical Parameters and Specifications}

\subsection{Expedient airfield design overview}

It should first be noted that the phrase "expedient airfield design" is generally a misnomer because the design process (including calculations, design charts, etc.) for an expedient airfield relates only to the runway. Additionally, FM 5-430-00-2 (1994, pg. 1-10, para. 1-44) states that for an expedient airfield, "[s]helter and utilities are provided by organic equipment" saying again that the design is strictly related to the runway. It should also be noted there are a number of different terms in different military technical manuals that are used to describe expedient runways (e.g., semi-improved, unsurfaced, expedient). To standardize nomenclature in this report, only the term "expedient" will be used.

An expedient runway design will give the engineer the location, length, and alignment of a runway. The design process for airfields in general is summed up by TM 3-34.48-2 (2016, pg. 2-9, para. 2-24). Since expedient airfields are a specialized type of airfield, however, steps were added to the design process (making 16 steps) to reflect the additional considerations required for expedient airfields. Since ENSITE/TASS is a remote planning tool, it should be noted that not all steps of the combined design process are applicable for remote planning. ENSITE/TASS incorporates only 8 of the 16 steps from the modified design process, which are subsequent listed and noted in sections 2.1-2.8 of this report. For full context, the remaining 8 steps are briefly covered in Section 2.9, with reference sources cited.

(Note that a component below that is followed by an asterisk $\left(^{*}\right)$ means the component is included in ENSITE/TASS, and ${ }^{* *}$ means it is not included.)
1. Select the runway location.*
2. Determine the design aircraft.*
3. Determine the in-place soil strength.*
4. Determine the required number of passes.*
5. Determine the allowable number of passes and surface type.*
6. Outline corrective actions to increase service list as necessary. ${ }^{* *}$
7. Determine the runway length and width.*
8. Determine approach zones and imaginary surfaces.*
9. Determine the runway orientation based on the wind rose.*
10. Design vertical slopes. ${ }^{* *}$ 
11. Design transverse slopes. ${ }^{* *}$

12. Design taxiways and aprons.**

13. Design required drainage structures.**

14. Select visual and nonvisual aids to navigation.**

15. Design logistical support facilities. ${ }^{* *}$

16. Design aircraft protection facilities. ${ }^{* *}$

\subsection{Select the runway location}

Expedient runways are used for tactical movement of personnel and supplies. Thus, when considering the location of a expedient runway, ENSITE/TASS users should take into account a number of factors that balance the practicality of construction and intended life span of the runway. That is to say, since the location of tactical operations and the military requirements to support those operations are likely to change quickly, only minimal resources should be committed to constructing an expedient runway. With the considerations in mind, TM 3-34.48-2 (2016, pg. 4-7, para. 4-27) suggests "natural areas such as deserts, dry lake beds, and flat valley floors" as viable options.

Wherever the user may select, the process of determining runway location has been partially automated in ENSITE/TASS. Since ENSITE/TASS is a remote planning tool, a single, specific runway cannot be selected. Rather, a geographic region can be selected based on mission, enemy, terrain and weather, troops and support available, time available, and civil considerations. ENSITE/TASS will then analyze the geographic region and suggest a location and an orientation for the expedient runway.

\subsection{Determine the design aircraft}

The design aircraft is the aircraft that represents the "most extreme load distribution characteristics" of all aircraft that will be utilizing the runway (TM 3-34.48-2 2016, pg. 4-5, para. 4-22). For ENSITE/TASS, the design aircraft will either be a $\mathrm{C}-17$ or $\mathrm{C}-130$. The ENSITE/TASS user will select one of these two aircraft based on the mission requirements given from higher headquarters.

The aircraft's gross weight, which is the basis for determining the needed pavement thickness, is the aircraft's maximum allowable weight during takeoff, and Table 1 shows that data for both aircraft types. It should be noted that TASS does not use these weights for preliminarylevel siting and 
design of expedient runwayss. Rather, these weights are provided as a benefit, in case the ENSITE/TASS user may want to estimate the number of passes for an aircraft of a certain type. ENSITE/TASS users can find more information on this topic in TM 3-34.48-2 (2016, pg. 4-5, para. 4-44).

Table 1. Design aircraft gross weight for use in expedient runway design (modified from FM 5-430-00-2 [1994]).

\begin{tabular}{|l|l|}
\hline Design Aircraft & Gross Weight (kips) \\
\hline C-130 & 130 \\
\hline C-17 & 447 \\
\hline
\end{tabular}

\subsection{Determine the in-place soil strength}

TM 3-34.48-2 (2016, pg. 4-8, para. 4-29) describes determining soil strength as "significant" in the process of expedient runway design. Ironically, this step represents a limitation with the current state-of-the-art for remote sensing of soil strength and, thus, a limitation of ENSITE/TASS capabilities. That is to say, there is no current technology that can remotely obtain the shear strength of soil. ENSITE/TASS, however, has a geographic database of Unified Soil Classification System (USCS) soil types (Table 2) that can be used to obtain an approximation of shear strength of soil in terms of California Bearing Ratio (CBR), the engineering parameter used ENSITE/TASS for pavement thickness design. This correlation of values is presented in Table 3 .

In addition to estimating shear strength, ENSITE/TASS methodology assumes that the soil's shear strength is uniform to a depth of 24 in., which is the depth required for analysis. 
Table 2. Unified Soil Classification System (modified from ETL 97-9 1997, Atch. 1, pg. 44, para. A.1).

\begin{tabular}{|c|c|c|c|}
\hline \multicolumn{3}{|c|}{ Major Divisions } & \multirow{2}{*}{$\begin{array}{c}\text { Symbol } \\
\text { GW }\end{array}$} \\
\hline \multirow{8}{*}{ 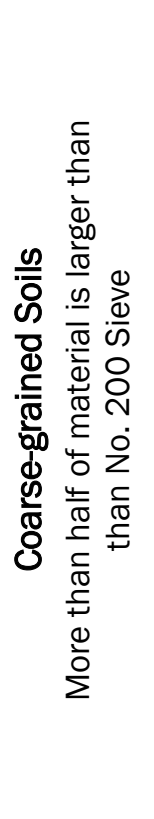 } & \multirow{4}{*}{ 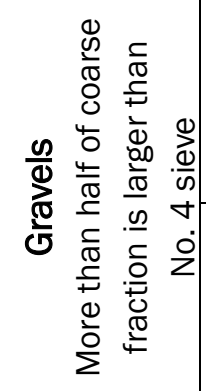 } & \multirow{2}{*}{$\begin{array}{c}\text { Gravels } \\
<5 \% \\
\text { Fines }\end{array}$} & \\
\hline & & & GP \\
\hline & & \multirow{2}{*}{$\begin{array}{c}\text { Gravels } \\
>12 \% \\
\text { Fines }\end{array}$} & GM \\
\hline & & & GC \\
\hline & \multirow{4}{*}{ 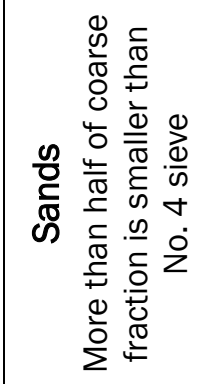 } & \multirow{2}{*}{$\begin{array}{c}\text { Sands } \\
>5 \% \\
\text { Fines }\end{array}$} & SW \\
\hline & & & SP \\
\hline & & \multirow{2}{*}{$\begin{array}{c}\text { Sands } \\
<12 \% \\
\text { Fines }\end{array}$} & SM \\
\hline & & & $\mathrm{SC}$ \\
\hline \multirow{6}{*}{ 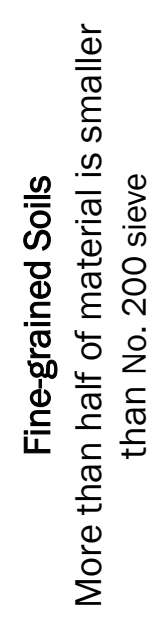 } & \multirow{3}{*}{\multicolumn{2}{|c|}{$\begin{array}{l}\text { Silts and Clays } \\
\qquad L L<50\end{array}$}} & ML \\
\hline & & & $\mathrm{CL}$ \\
\hline & & & OL \\
\hline & \multirow{3}{*}{\multicolumn{2}{|c|}{$\begin{array}{l}\text { Silts and Clays } \\
\qquad L L>50\end{array}$}} & MH \\
\hline & & & $\mathrm{CH}$ \\
\hline & & & $\mathrm{OH}$ \\
\hline \multicolumn{3}{|c|}{ Highly Organic Soils } & Pt \\
\hline
\end{tabular}


Table 3. Estimated CBR values for USCS classified soils (modified after ARA, Inc.-ERES Division 2001, pg. CC 1-10, Table 5).

\begin{tabular}{|c|c|}
\hline USCS Symbol & Estimated CBR \\
\hline GW & 64 \\
\hline GP & 53 \\
\hline GM & 52 \\
\hline GC & 19 \\
\hline SW & 36 \\
\hline $\mathrm{SP}$ & 28 \\
\hline $\mathrm{SM}$ & 39 \\
\hline $\mathrm{SC}$ & 16 \\
\hline $\mathrm{ML}$ & 11 \\
\hline $\mathrm{CL}$ & 8 \\
\hline $\mathrm{MH}$ & 5 \\
\hline $\mathrm{CH}$ & 3 \\
\hline
\end{tabular}

\subsubsection{Discussion on the relationship between USCS soil type and CBR}

When estimating CBR based on USCS soil type, TM 3-34.48-2 (2016, pg. 4-66, para. 4-233) recommends using the lowest value given by Table B-4 in TM 3-34.43 (2015, pg. B-20), which is presented below as Table 4. Using the lowest value will give a conservative estimate of CBR. The issue, however, is that the estimate may be overly conservative and may preclude potentially viable airfield orientations during the planning process, based on nothing other than the desire to be conservative. Thus, the values presented in Table 2 are provided to give a reasonable estimate based on empirical work.

In addition to Table 4 being presented as Table B-4 in TM 3-34.43 (2015, pg. B-20), it is also available as Table 5-3 in TM 3-34.64 (2012, pg. 5-13). 
Table 4. Characteristics of soil groups pertaining to roads and airfields

(modified from TM 3-34.43 [2015]).

\begin{tabular}{|c|c|c|c|c|c|c|c|}
\hline \multirow{2}{*}{$\begin{array}{l}\text { Value As Base } \\
\text { When not Subject } \\
\text { to Frost Action } \\
\text { (9) }\end{array}$} & \multirow{2}{*}{\begin{tabular}{|c|} 
Potential \\
Frost \\
Action \\
$(10)$
\end{tabular}} & \multirow{2}{*}{$\begin{array}{c}\text { Compressibility } \\
\text { and Expansion } \\
\text { (11) }\end{array}$} & \multirow{2}{*}{$\begin{array}{c}\text { Drainage } \\
\text { Characteristics } \\
\text { (12) }\end{array}$} & \multirow[b]{2}{*}{$\begin{array}{l}\text { Compaction } \\
\text { Equipment (13) }\end{array}$} & \multirow{2}{*}{$\left|\begin{array}{c}\text { Dry Unit } \\
\text { Weight } \\
\text { (pcf) (14) }\end{array}\right|$} & \multicolumn{2}{|c|}{ Typical Design Values } \\
\hline & & & & & & \begin{tabular}{l|l} 
CBR \\
$(15)$
\end{tabular} & $\begin{array}{c}\begin{array}{c}\text { Subgrade Modulus } \\
\mathrm{k} \text { (Ib per cu in) } \\
(16)\end{array} \\
\end{array}$ \\
\hline Good & \begin{tabular}{|l|}
$\begin{array}{l}\text { None to } \\
\text { very slight }\end{array}$ \\
\end{tabular} & Almost none & Excellent & $\begin{array}{l}\text { Crawler-type tractor, rubber-tired } \\
\text { roller, steel-wheeled roller }\end{array}$ & $125-140$ & $\begin{array}{ll}40- \\
80\end{array}$ & $300-500$ \\
\hline Fair to Good & $\begin{array}{l}\text { None to } \\
\text { very slight }\end{array}$ & Almost none & Excellent & $\begin{array}{l}\text { Crawler-type tractor, rubber-tired } \\
\text { roller, steel-wheeled roller }\end{array}$ & $110-140$ & $30-$ & $300=500$ \\
\hline Fair to Good & $\begin{array}{l}\text { Slight to } \\
\text { medium }\end{array}$ & Very slight & Fair to poor & $\begin{array}{l}\text { Rubber-tired roller, sheepsfoot } \\
\text { roller, close control of moisture }\end{array}$ & $125-145$ & $68-$ & $300-500$ \\
\hline $\begin{array}{l}\text { Poor to not } \\
\text { suitable }\end{array}$ & $\begin{array}{l}\text { Slight to } \\
\text { medium }\end{array}$ & Slight & $\begin{array}{l}\text { Poor to practi- } \\
\text { cally impervious }\end{array}$ & $\begin{array}{l}\text { Rubber-tired roller, } \\
\text { sheepsfoot roller }\end{array}$ & $115-135$ & $20-$ & $200-500$ \\
\hline $\begin{array}{l}\text { Poor to not } \\
\text { suitable }\end{array}$ & $\begin{array}{l}\text { Slight to } \\
\text { medium }\end{array}$ & Slight & $\begin{array}{l}\text { Poor to practi- } \\
\text { cally impervious }\end{array}$ & $\begin{array}{l}\text { Rubber-tired roller, } \\
\text { sheepsfoot roller }\end{array}$ & $130-145$ & \begin{tabular}{l|l}
$20-$ \\
40
\end{tabular} & $200-500$ \\
\hline Poor & $\begin{array}{l}\text { None to } \\
\text { very slight }\end{array}$ & Almost none & Excellent & $\begin{array}{l}\text { Crawler-type tractor, rubber-tired } \\
\text { roller, steel-wheeled roller }\end{array}$ & $110-130$ & \begin{tabular}{l|l|}
$20-$ \\
40
\end{tabular} & $200-400$ \\
\hline $\begin{array}{l}\text { Poor to not } \\
\text { suitable }\end{array}$ & $\begin{array}{l}\text { None to } \\
\text { very slight }\end{array}$ & Almost none & Excellent & $\begin{array}{l}\text { Crawler-type tractor, rubber-tired } \\
\text { roller, steel-wheeled roller }\end{array}$ & $105-135$ & $\begin{array}{ll}10- \\
40\end{array}$ & $150-400$ \\
\hline Poor & $\begin{array}{l}\text { Slight to } \\
\text { high }\end{array}$ & Very slight & Fair to poor & $\begin{array}{l}\text { Rubber-tired roller, sheepsfoot } \\
\text { roller; close control of moisture }\end{array}$ & $120-135$ & $\begin{array}{ll}15- \\
40^{-}\end{array}$ & $150-400$ \\
\hline Not suitable & $\begin{array}{l}\text { Slight to } \\
\text { high }\end{array}$ & \begin{tabular}{|l|} 
Slight to \\
medium
\end{tabular} & \begin{tabular}{|l|}
$\begin{array}{l}\text { Poor to practi- } \\
\text { cally impervious }\end{array}$ \\
\end{tabular} & $\begin{array}{l}\text { Rubber-tired roller, sheepsfoot } \\
\text { roller }\end{array}$ & $100-130$ & $\begin{array}{l}10- \\
20 \\
\end{array}$ & $100-300$ \\
\hline Not suitable & $\begin{array}{l}\text { Slight to } \\
\text { high }\end{array}$ & $\begin{array}{l}\text { Slight to } \\
\text { medium }\end{array}$ & \begin{tabular}{|l|}
$\begin{array}{l}\text { Poor to practi- } \\
\text { cally impervious }\end{array}$ \\
\end{tabular} & $\begin{array}{l}\text { Rubber-tired roller, } \\
\text { sheepsfoot roller }\end{array}$ & $100-135$ & $5=$ & $100-300$ \\
\hline Not suitable & $\begin{array}{l}\text { Medium to } \\
\text { very high }\end{array}$ & $\begin{array}{l}\text { Slight to } \\
\text { medium }\end{array}$ & Fair to poor & $\begin{array}{l}\text { Rubber-tired roller, } \\
\text { sheepsfoot roller; close } \\
\text { control of moisture } \\
\end{array}$ & $90-130$ & $\begin{array}{l}15 \text { or } \\
\text { less }\end{array}$ & $100-200$ \\
\hline Not suitable & $\begin{array}{l}\text { Medium to } \\
\text { high }\end{array}$ & Medium & $\begin{array}{l}\text { Practically } \\
\text { impervious }\end{array}$ & $\begin{array}{l}\text { Rubber-tired roller, } \\
\text { sheepsfoot roller }\end{array}$ & $90-130$ & $\begin{array}{l}15 \text { or } \\
\text { less }\end{array}$ & $50-150$ \\
\hline Not suitable & $\begin{array}{l}\text { Medium to } \\
\text { high }\end{array}$ & Medium to high & Poor & $\begin{array}{l}\text { Rubber-tired roller, } \\
\text { sheepsfoot roller }\end{array}$ & $90-105$ & $\begin{array}{l}5 \text { or } \\
\text { less }\end{array}$ & $50-100$ \\
\hline Not suitable & $\begin{array}{l}\text { Medium to } \\
\text { very high }\end{array}$ & High & Fair to poor & $\begin{array}{l}\text { Rubber-tired roller, } \\
\text { sheepsfoot roller }\end{array}$ & $80-105$ & $\begin{array}{l}10 \text { or } \\
\text { less }\end{array}$ & $50-100$ \\
\hline Not suitable & Medium & High & $\begin{array}{l}\text { Practically } \\
\text { impervious }\end{array}$ & $\begin{array}{l}\text { Rubber-tired roller, } \\
\text { sheepsfoot roller }\end{array}$ & $90-115$ & $\begin{array}{l}15 \text { or } \\
\text { less }\end{array}$ & $50-150$ \\
\hline Not suitable & Medium & High & \begin{tabular}{|l} 
Practically \\
impervious
\end{tabular} & $\begin{array}{l}\text { Rubber-tired roller, } \\
\text { sheepsfoot roller }\end{array}$ & $80-110$ & \begin{tabular}{|l}
5 or \\
less
\end{tabular} & $25-100$ \\
\hline Not suitable & Slight & Very high & Fair to poor & Compaction not practical & - & - & - \\
\hline
\end{tabular}

\subsection{Determine the required number of passes}

The required number of passes $^{2}$ is determined from mission requirements. For expedient runways without a parallel taxiway, which is often the case, the required passes should be multiplied by 2 to account for aircraft using the runway for taxiing operations (TM 3-34.48-2 2016, pg. 4-6, para. 4-24). The number of required passes is used as a metric of whether a potential runway can sustain the mission's need for aircraft operations. That is, the required passes are checked against the allowable number of passes to determine suitability.

\subsection{Determine the allowable number of passes and surface type}

The allowable number of passes is determined by using the data shown in Figure 1, producing a graph of allowable passes by aircraft type.

\footnotetext{
2 A pass herein is defined as one takeoff and one landing.
} 
Figure 1. Plot correlating passes and CBR

(modified from TM 3-34.48-2 [2016]), pg. 4-7, para. 4-29).

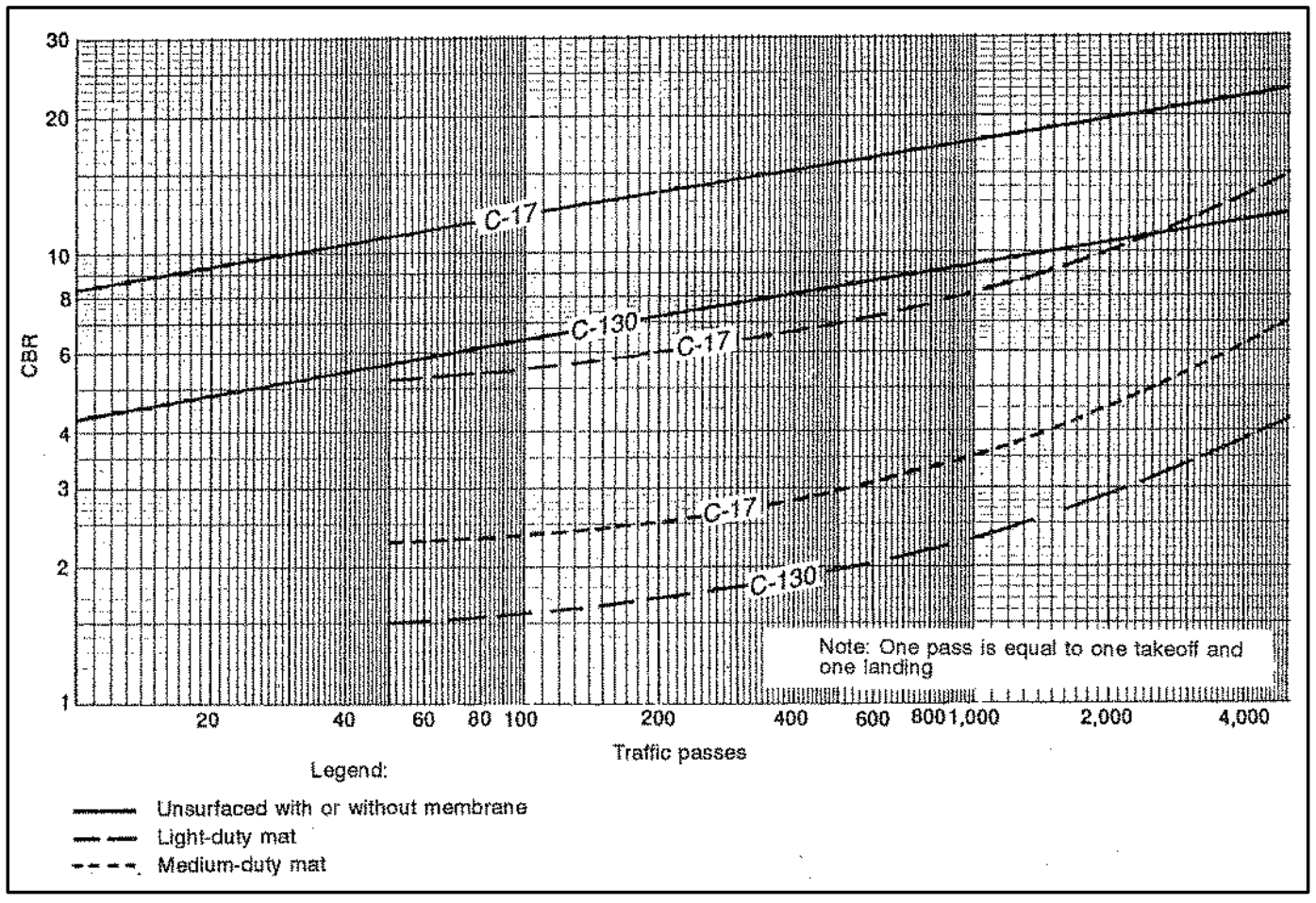

If the required number of passes exceeds the allowable number of passes, then geosynthetics (i.e., matting) or soil stabilization methods will be required to strengthen the expedient runway's surface. At the time of this writing, runway design that requires soil modification via geosynthetics or stabilization is not included in ENSITE/TASS. It should be noted that geosynthetics were left out of this writing because they represent a level of effort and training that is outside the intended use of ENSITE/TASS as well as outside the capability of the typical military engineering unit.

\subsection{Determine the runway length and width}

What is commonly referred to collectively as a "runway" is actually composed of a number of different areas or zones (e.g., runway, shoulders, and overrun). When considering the length and width of a runway, the socalled "imaginary surfaces" (e.g., primary surface, approach-departure surface, inner horizontal surface) that are associated with airfields should also be considered. These surfaces represent boundaries in the airspace surrounding the airfield that must be clear of obstructions to aircraft (refer to Figure 4-Figure 6). 
Expedient runways, however, have different imaginary surfaces than other types of runways. These imaginary surfaces are discussed in subsection 2.7.2. Runway design in ENSITE/TASS is focused on $\mathrm{C}-130$ s and $\mathrm{C}-17 \mathrm{~s}$ in the decisive and support areas within the theater of operations.

Runway length, which is generally referred to as "takeoff ground run" (TGR) and runway width are based on designed charts for specific aircraft and airfield types. Runway length is determined by adjusting the minimum TGR for pressure altitude, temperature, and effective gradient as well as applying a safety factor. It should be noted that, once TGR length is determined, that length is augmented with overruns and a number of imaginary surfaces which then extends the total length of the runway. ENSITE/TASS calculates TGR by using the following procedure quoted from TM 3-34.48-2 (2016), pg. 2-10, para. 2-2:

1. Determine the standard TGR for an aircraft from Table 2 in ETL 09-6 (2009, Atch. 2, pg. 4).

2. Correct for pressure altitude. Add the pressure altitude of the site, which can be obtained from Figure 2, to the geographic altitude. Increase TGR by $10 \%$ for each $1,000 \mathrm{ft}$ increase in altitude above $1,000 \mathrm{ft}$. No reduction in TGR is permitted if the pressure altitude is less than $1,000 \mathrm{ft}$.

3. Correct for temperature. If the pressure-corrected TGR is equal to or greater than $5,000 \mathrm{ft}$, increase the pressure-corrected TGR by $7 \%$ for each $10^{\circ} \mathrm{F}$ increase in temperature above $59^{\circ} \mathrm{F}$ (from [Figure 3]). If the pressure-corrected TGR is less than $5,000 \mathrm{ft}$, increase the pressurecorrected TGR by $4 \%$ for each $10^{\circ} \mathrm{F}$ increase above $59^{\circ} \mathrm{F}$. Never decrease the runway length if the temperature is less than $59^{\circ} \mathrm{F}$.

4. Adjust for safety. Multiply the temperature corrected TGR by 1.5 for sustaining area airfields and by 1.25 for support and decisive area airfields.

5. Correct for effective gradient. Increase the safety-corrected TGR by $8 \%$ for each $1 \%$ increase of effective gradient over $2 \%$. No reduction in TGR is permitted if the effective gradient is flatter than $2 \%$.

6. Round off the gradient-corrected TGR to the next higher $100 \mathrm{ft}$.

7. Compare the computed value of the TGR with the minimum require runway length. Use the higher of the two values. 
For planning and computational purposes, the effective gradient in TASS is assumed to be 3 , which is the maximum gradient of a expedient runway in the decisive area.

Runway width is primarily determined by (1) the safety of operating aircraft in conditions of reduced visibility and (2) the lateral stability and control of the aircraft during final approach and landing (TM 3-34.48-2 2016, pg. 2-12, para. 2-30). The airfield type (i.e., decisive area, support area) is a secondary consideration. For a runway located in the decisive or support areas, the runway width is $90 \mathrm{ft}$ for a $\mathrm{C}-17$ and $60 \mathrm{ft}$ for a $\mathrm{C}-130$, plus an additional $10 \mathrm{ft}$ on either side, making the total widths 110 or $80 \mathrm{ft}$, respectively (ETL 09-6 2009, Atch. 2, pg. 4, Table 2).

\subsubsection{Runway length design example.}

- Problem: Consider a C-17 operating near Champaign, IL.

- Assumptions:

○ Effective gradient, $\mathrm{i}_{\mathrm{e}},=0.015$

- Geographic altitude, $\mathrm{H},=764 \mathrm{ft}$

- Runway is in the decisive area

- Find: Required takeoff ground run (TGR; i.e., runway length)

- Solution:

- The standard TGR for a C-17 was obtained from Table 2 in (ETL o96 2009, Atch. 2, pg. 2-2) and is 3,500 ft.

- The pressure altitude, $d H$, was obtained from Figure 2 (page 13)and is approximately $350 \mathrm{ft}$. Adding the geographic altitude and the pressure altitude gives the following computations:

$$
\begin{gathered}
H_{t}=H+d H \\
H_{t}=764 f t+350 f t \\
H_{t}=1114 f t
\end{gathered}
$$

The procedure for correcting TGR for pressure altitude is to increase the TGR by $10 \%$ for each $1,000 \mathrm{ft}$ increase above $1,000 \mathrm{ft}$. The difference between the reference altitude and the total altitude is $114 \mathrm{ft}$ (i.e., $1,114 \mathrm{ft}-$ $1,000 \mathrm{ft}=114 \mathrm{ft}$ ). This is less than the $100 \mathrm{ft}$ threshold, so no correction is warranted for pressure altitude in this example. 
The maximum average temperature was obtained from Figure 3 (page 14) and is approximately $85^{\circ} \mathrm{F}$. The difference between the reference average maximum temperature and the geographic average maximum temperature is $26^{\circ} \mathrm{F}$ (i.e., $85^{\circ} \mathrm{F}-59^{\circ} \mathrm{F}=26^{\circ} \mathrm{F}$ ). This temperature is above the $10^{\circ} \mathrm{F}$ threshold. Considering that the pressure-corrected TGR is less than 5,000 $\mathrm{ft}$, the TGR will then be increased by $8 \%$ (i.e., $4 \%$ for every $10^{\circ} \mathrm{F}$ above $59^{\circ}$ for pressure-corrected TGRs less than $5,000 \mathrm{ft}$ ). The TGR is now calculated as follows:

$$
\begin{gathered}
T G R=3500 f t * 1.08 \\
T G R=3780 f t
\end{gathered}
$$

Since the runway is in the decisive area, the safety factor is 1.25 . The TGR is now calculated as follows:

$$
\begin{gathered}
T G R=3780 f t * 1.25 \\
T G R=4725 f t
\end{gathered}
$$

The difference between the reference effective gradient and the assumed effective gradient is $1 \%$ (i.e., $3 \%-2 \%=1 \%$ ). The TGR will then be increased by $1 \%$. The TGR is now:

$$
\begin{gathered}
T G R=4275 f t * 1.01 \\
T G R=4772.25 f t
\end{gathered}
$$

which, when rounded up to the next $100 \mathrm{ft}$, is $4,800 \mathrm{ft}$. Because this distance is greater than the minimum required, the TGR is thus $4,800 \mathrm{ft}$. 
Figure 2. Isopleths of pressure altitude (from TM 3-34.48-2 [2016], p. 2-11).

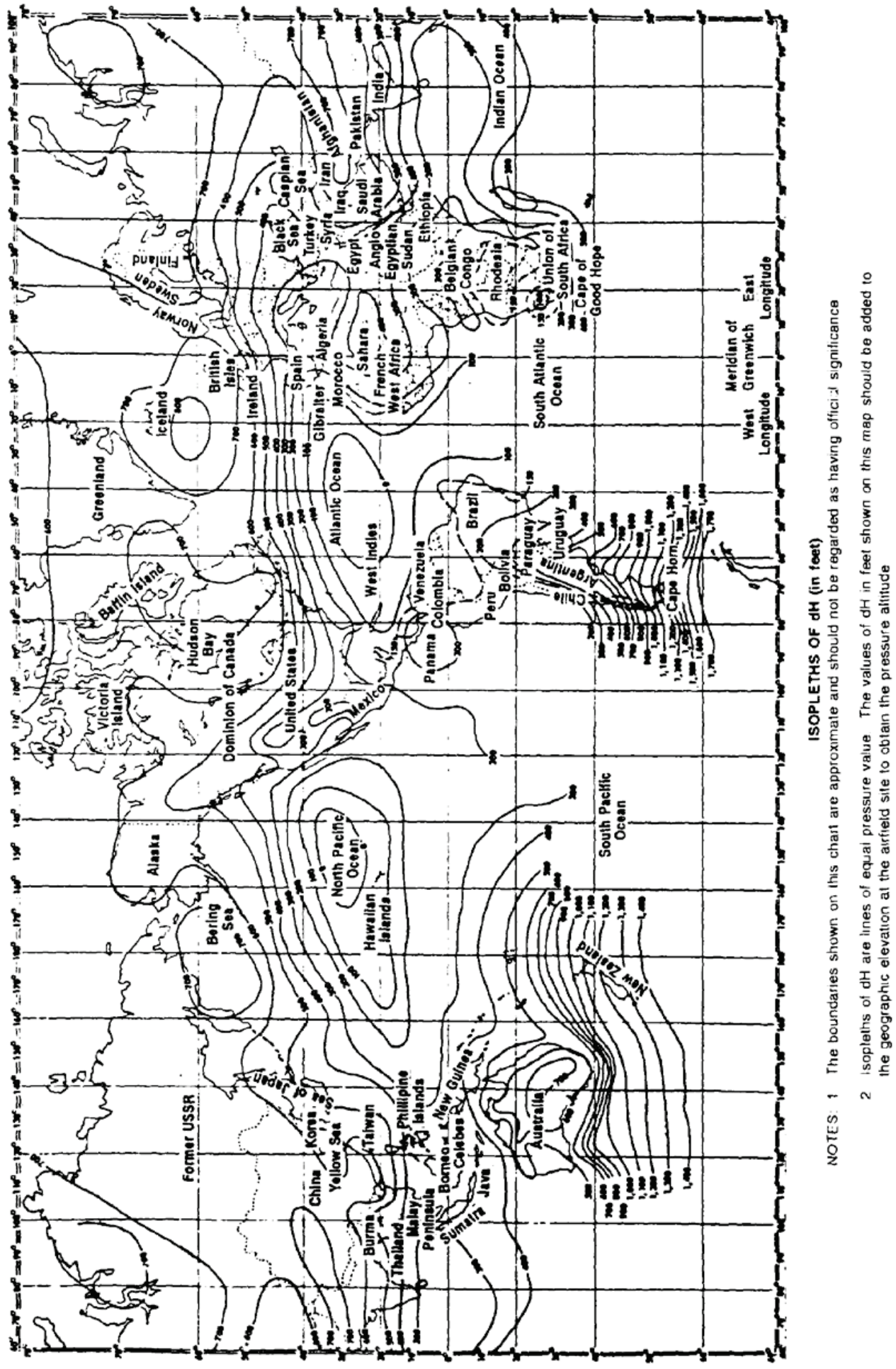


Figure 3. Isopleths of average maximum temperature (from TM 3-34.48-2 [2016], p. 2-12).

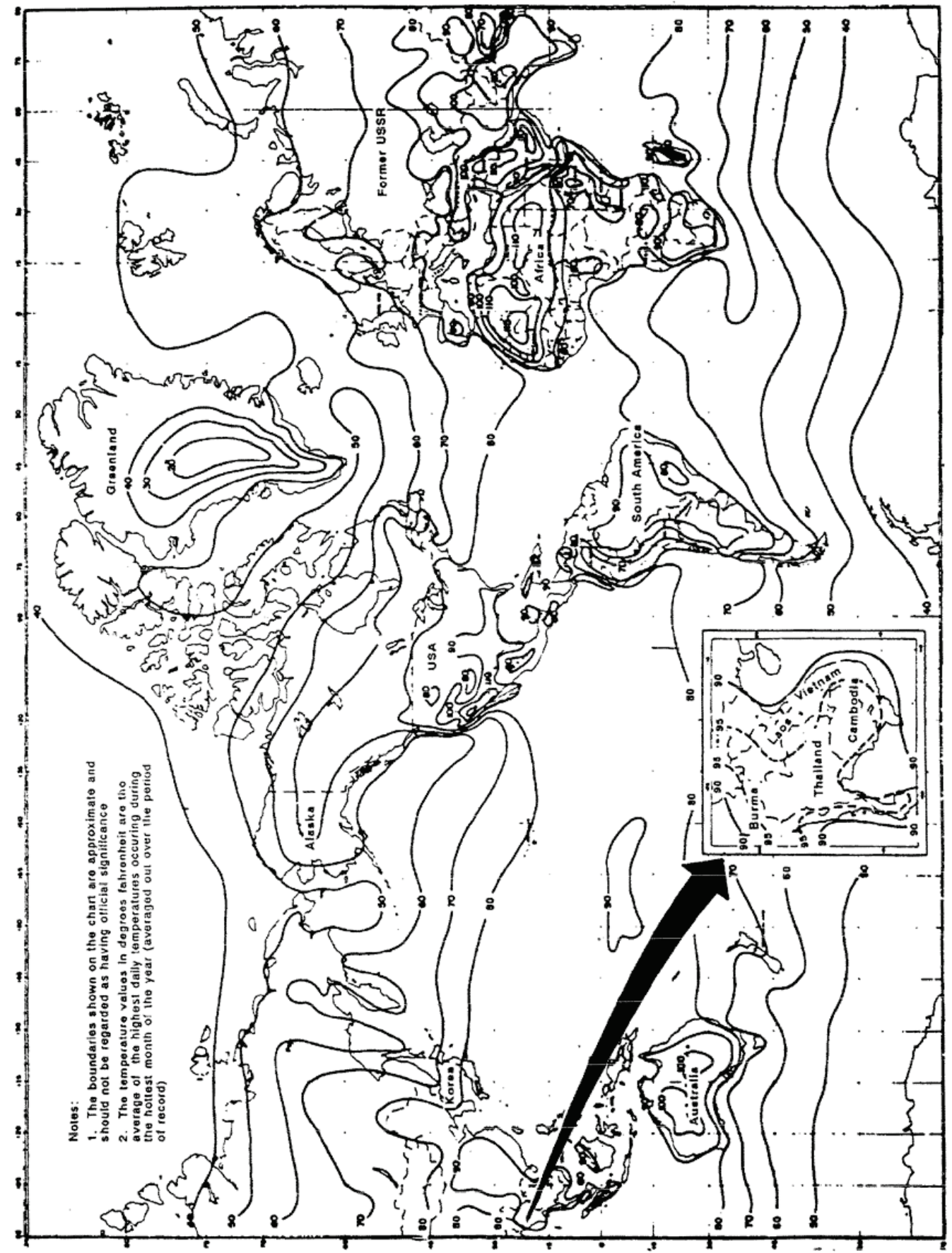

\subsubsection{Determine approach zones and imaginary surfaces}

A runway is composed of a number of elements, such as the TGR, overruns, and other imaginary surfaces. Expedient runways do not have the 
same elements as runways at established airfields. The elements of expedient runways are described by TM 3-34.48-2 (2016, pg. 2-8) and are presented verbatim below:

1. Accident potential zone-LZ. An accident potential zone-LZ is a land use control area beyond the clear zone of an LZ that possesses a significant potential for accidents; therefore, land use is a concern.

2. Clear zone landing zone (LZ). A clear zone LZ is a surface on the ground or water, beginning at the runway threshold and symmetrical about the extended runway centerline. It is graded to protect aircraft operation in which only properly sited [navigational aids] are allowed.

3. Overruns. An overrun is an area that is the width of the runway, plus prepared shoulders, extending 300 feet from the end of the runway into the clear zone. This portion is a prolongation of the runway and is constructed to support aircraft traffic.

4. Primary surface. A primary surface is an imaginary surface that is symmetrically centered on the runway. The elevation of any point on the primary surface is the same as the elevation of the nearest point of beginning for the runway and airspace imaginary surfaces will be determined.

5. Approach-departure clearance surfaces. An approach-departure clearance surface is an imaginary surface that is an inclined plane or combined inclined and horizontal planes arranged symmetrically about the extended runway centerline. Objects that penetrate this surface are considered obstructions to air navigation and should be removed if possible. If they are not removed, they must be mapped, marked, and lighted as obstructions. The first segment or the beginning of the inclined plane coincides with the ends and edges of the primary surface and the elevation of the centerline at the runway end. This surface flares outward and upward from these points.

These zones increase the space requirements of a runway and are presented in Figure 4-Figure 6 below. 
Figure 4. Runway end detail in plan view (from ETL 09-6 [2009], Atch. 1, pg. 1).

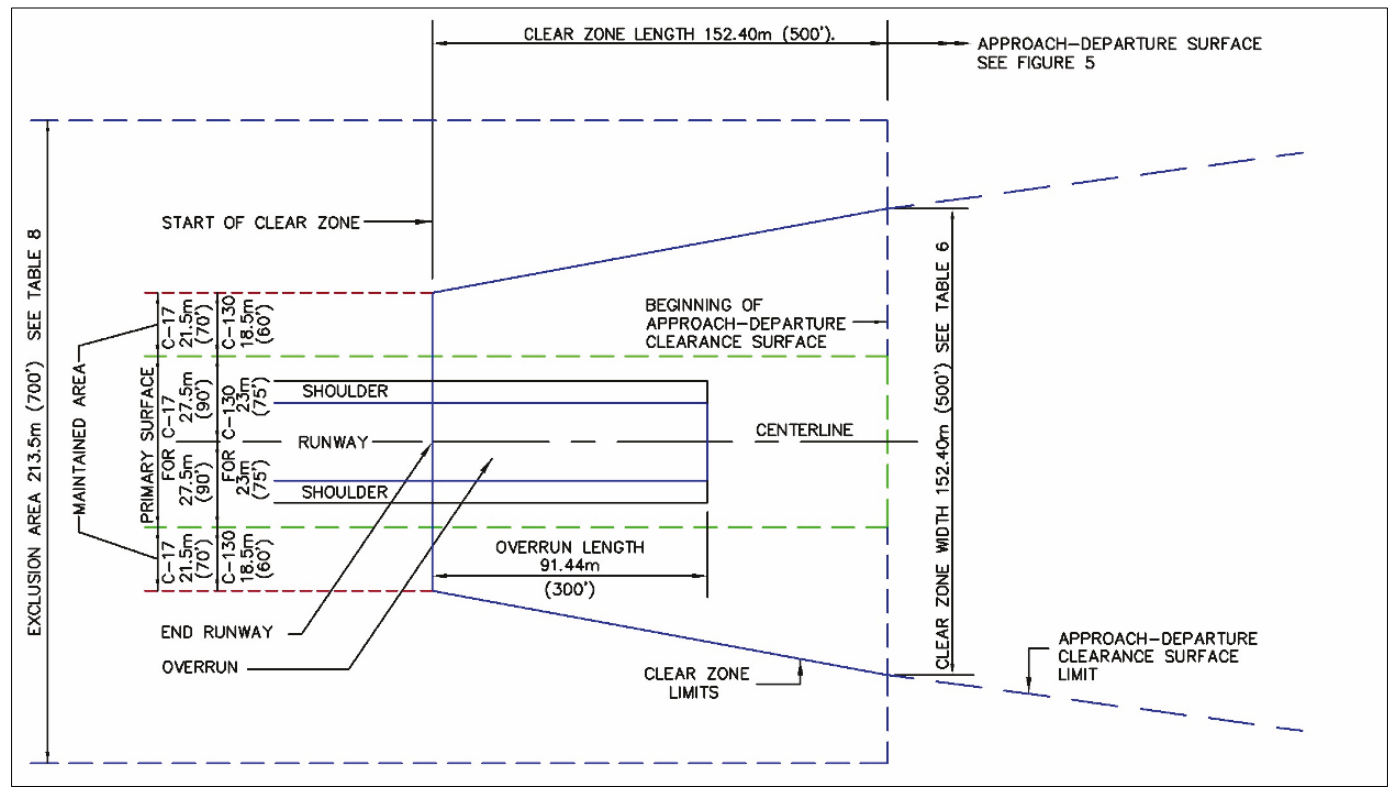

Figure 5. Runway end detail in profile view (from ETL 09-6 [2009], Atch. 1, pg. 1).

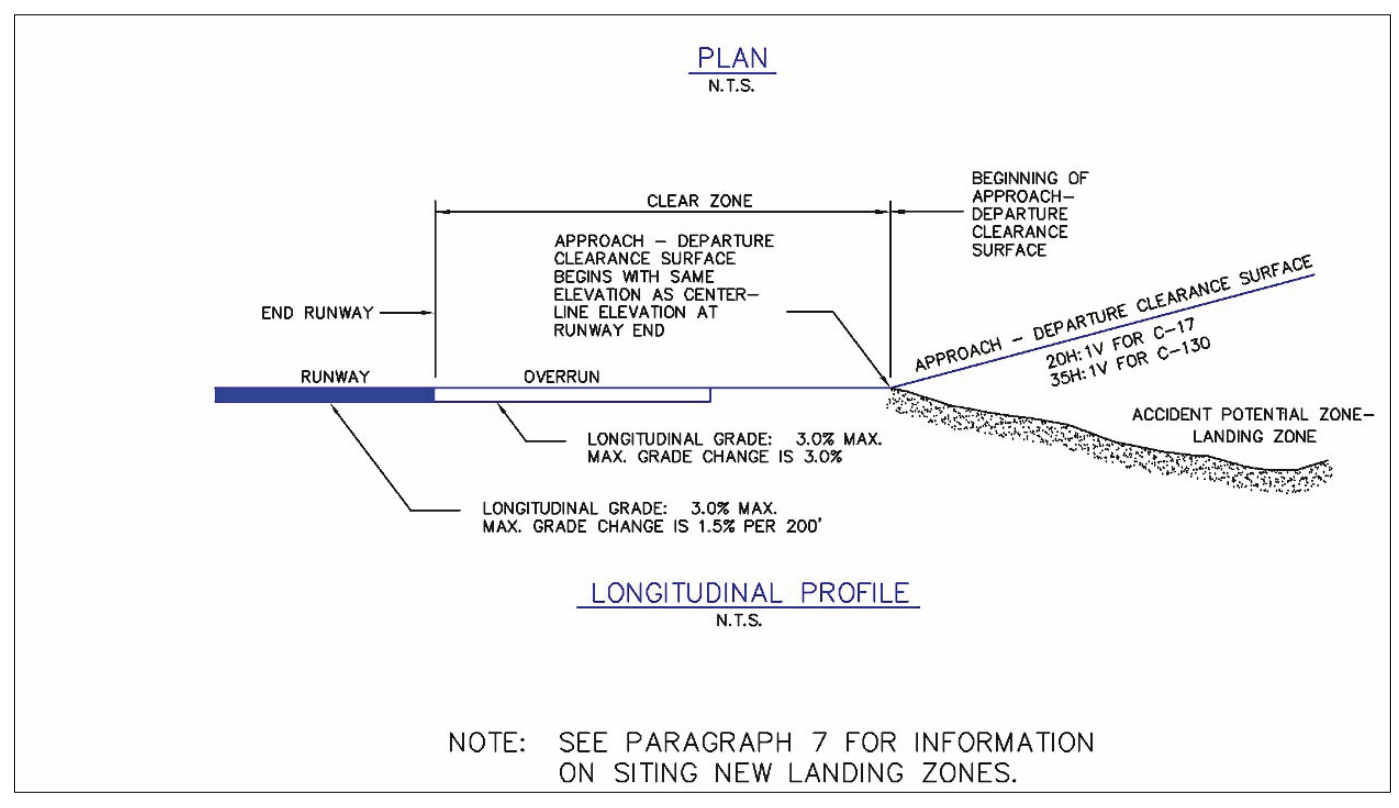


Figure 6. Runway end details in plan view showing the accident-potential zone (from ETL 09-6 [2009], Atch. 1, pg. 2).

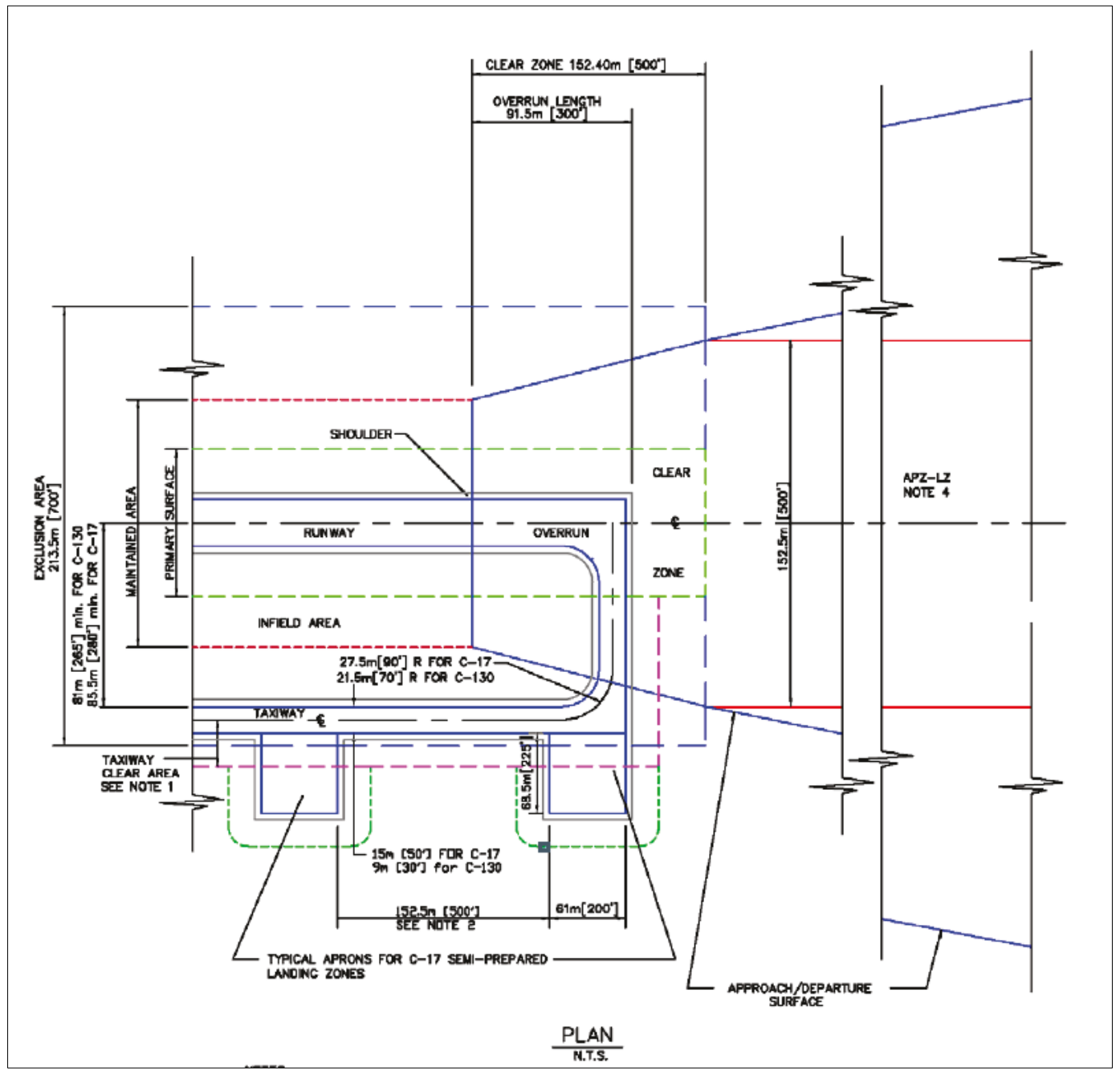

\subsubsection{Turnarounds}

It is likely that an expedient runway will not have taxiways, as does a more permanent airfield. Thus, turnarounds must be constructed at both ends of the runway (ETL 09-6 2009, pg. 11, para. 8.1.5). These turnarounds must be sized for the design aircraft. Turnarounds for the $\mathrm{C}-17$ should be $180 \times 165 \mathrm{ft}$ with $45^{\circ}$ fillets and, for the C-130, a turnaround needs to be 75 $\mathrm{ft}$ in diameter (Figure 7; (ETL 09-6 2009, Atch. 2, pg. 4). 
Figure 7. Schematic diagram of a turnaround (after ETL 09-6 [2009], Atch. 1, pg. 3).

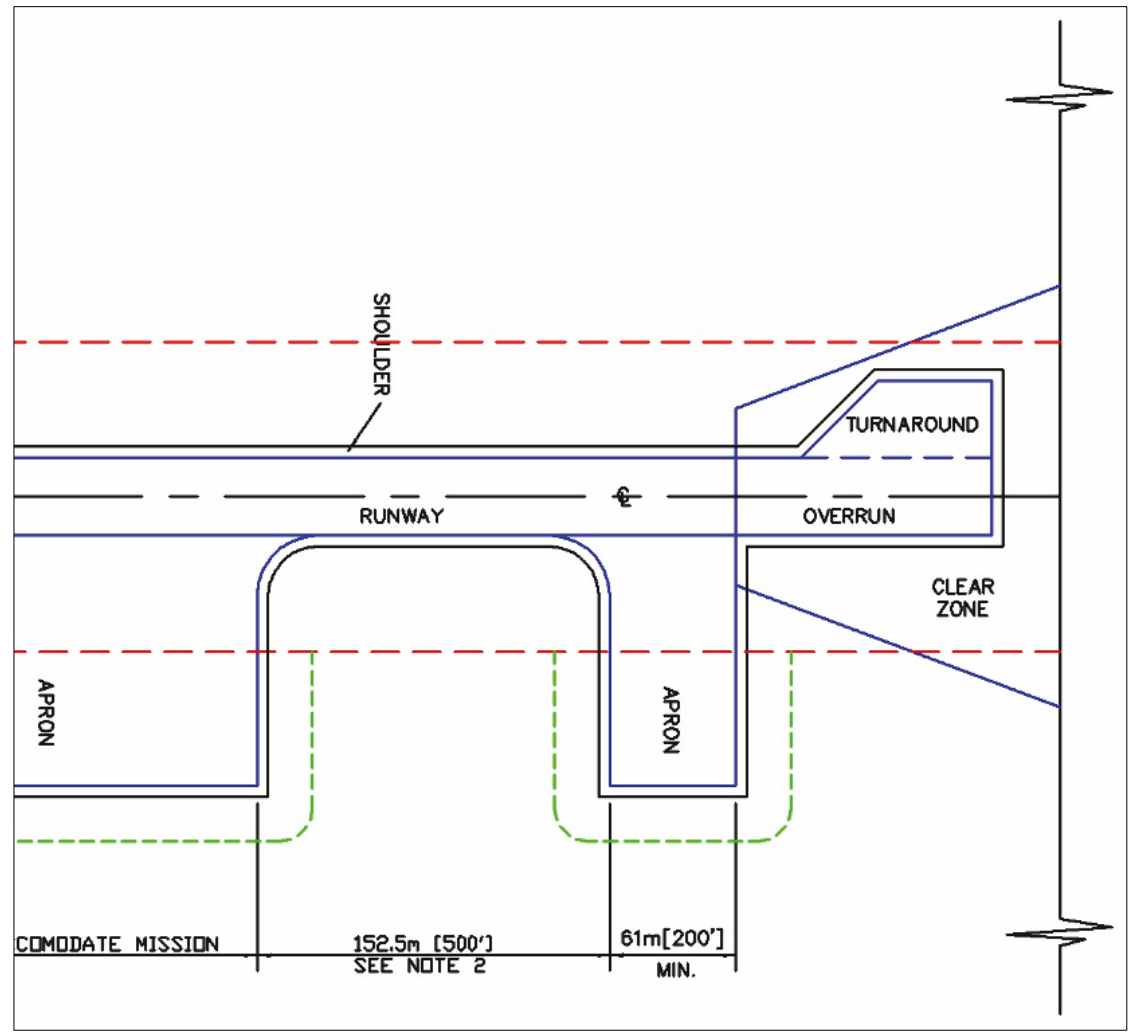

\subsection{Determine the runway orientation}

Runways are oriented with consideration to the prevailing winds in the area (TM 3-34.48-2 2016, pg. 2-15, para. 2-50). Under ideal conditions, a minimum of 10 years of data is used to determine wind direction, velocity, and frequency of occurrence. Using this 10 years of data, the runway would be oriented such that there is $80 \%$ wind coverage and a maximum beam wind of $13 \mathrm{mph}$ (TM 3-34.48-2 2016, pg. 2-15, para. 2-51).

Since ENSITE/TASS is a remote planning intended for use in tactical environments, it does contain limited wind data (e.g., wind speed for engineering design), though it does not contain wind data at every level of detail. To work around this limitation, the runway orientation in ENSITE/TASS is controlled by the $13 \mathrm{mph}$ beam wind and determined by using the wind vector. Further discussion and an example are given in subsections 2.8.1 and 2.8.2.

The criteria for orienting the runway given in the preceding paragraphs (i.e., 80\% wind coverage and $13 \mathrm{mph}$ beam wind) are related to the operating capacity of an aircraft and its pilot. In addition to operating capacity, 
the direction of the prevailing winds is also considered because of hazards created by dust (TM 3-34.48-2 2016, pg. 2-15, para. 2-51). If dusty conditions pose a hazard to safe operation on the runway, the runway may be oriented $10^{\circ}$ off the prevailing wind so that dust will be blown away from the runway (TM 3-34.48-2 2016, pg. 2-15, para. 2-51). TASS does not account for dust hazards when suggesting a runway orientation, however, since that type of information can only reasonable be ascertained by onsite personnel.

\subsubsection{Discussion and further guidance on the $13 \mathrm{mph}$ beam wind criterion}

The $13 \mathrm{mph}$ beam wind criteria is given in TM 3-34.48 (2016, pg. 2-15, para. 2-51) without citation. That is to say, the origin of this wind criterion is unclear. Without a clear understanding of the criterion's intent, it can be difficult for ENSITE/TASS users to determine the optimal expedient runway orientation. Thus, a brief discussion on this criteria is presented here, in case ENSITE/TASS users require more flexibility when siting a expedient runway.

It should first be noted that expedient runway orientations outside those suggested by ENSITE/TASS may still be feasible options. Indeed, (TM 334.48-2 2016, pg. 2-15, para. 2-51) states, with regard to the $80 \%$ wind coverage and $13 \mathrm{mph}$ beam wind criteria, "[these requirements] should not cause rejection of a site that is otherwise favorable." Conversely, a discussion with the Air Force Civil Engineer Center (AFCEC) Pavements Engineer revealed that the runway orientation should stay within the given criteria "to the maximum extent possible" 3 . Ultimately, if a runway must be oriented such that it does not meet the given criteria, the runway orientation should be done for reasons of military necessity and in collaboration with an aviation subject matter expert.

\subsubsection{Runway orientation example}

Problem: Consider an $18 \mathrm{mph}$ wind coming from $020^{\circ}$ (Figure 8).

3 Phone conversation by author Gamez with Craig Rutland of AFCEC in February 2018. 
Figure 8. Wind vector example (ERDC-CERL).

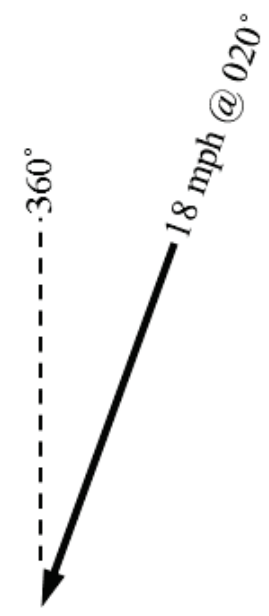

Find: Determine the maximum angle from the wind that a expedient runway can be oriented.

Solution: The maximum angle from the wind that a expedient runway can oriented can be found by considering the $13 \mathrm{mph}$ beam wind. In other words, the maximum wind perpendicular to the runway should not exceed $13 \mathrm{mph}$. To determine the angle at which this occurs, break down the wind vector into its components (Figure 9). The angle $\theta^{4}$ gives the maximum angle from the wind that a runway should be oriented.

Figure 9. Wind vector components (ERDC-CERL).

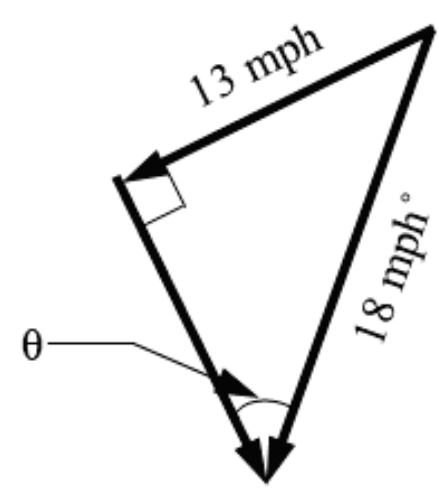

\footnotetext{
${ }^{4} \mathrm{~A}$ plane angle in geometry; an unknown variable in trigonometry.
} 
The value of $\theta$ can be obtained in a number of ways. In this example, it is found by using the trigonometric equation sequence below:

$$
\begin{gathered}
\sin \theta=\frac{\text { opposite }}{\text { hypotenuse }} \\
\sin \theta=\frac{13 \mathrm{mph}}{18 \mathrm{mph}} \\
\theta=\sin ^{-1}\left(\frac{13 \mathrm{mph}}{18 \mathrm{mph}}\right) \\
\theta=46.2^{\circ} \approx 46^{\circ}
\end{gathered}
$$

Given that $\theta=46^{\circ}$, the runway can be oriented up to $46^{\circ}$ off the direction of the predominant wind (Figure 10). Therefore the runway can be oriented $46^{\circ}$ either clockwise or counterclockwise from the direction of the wind (i.e., $066^{\circ}$ or $334^{\circ}$ in this example).

Figure 10. Determination of runway orientation (ERDC-CERL).

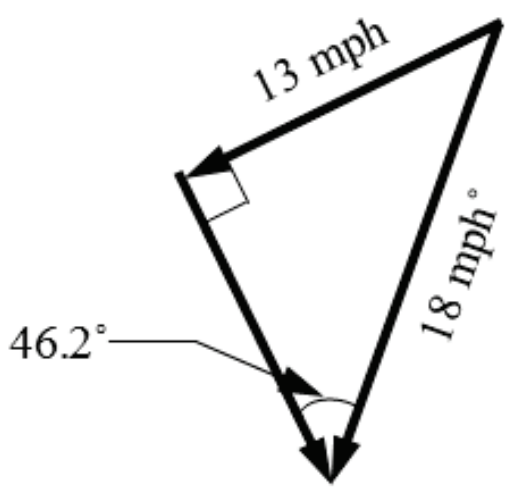

\subsubsection{True north vs. magnetic north}

It should be noted that wind direction is given with regard to the true north (TM 3-34-48-2 2016, pg. 2-23, para. 2-64). Runway directional numbers, however, are given with regard to magnetic north. Thus, ENSITE/TASS users must ensure that runway directional numbers are correctly assigned during the appropriate part of the design process. 


\subsection{Design components excluded from consideration}

By their nature, expedient airfields are short-term, quickly designed facilities without an expected long-term operational life span. Because of this, several design components associated with more permanent airfield installations are excluded. Additionally, ENSITE/TASS is a remote planning tool, and several design components require on-site survey data that is not remotely available; components needing such data were also omitted. A list of omitted design components and their related references are presented below in Table 5 .

Table 5. Airfield design components eliminated from consideration in TASS.

\begin{tabular}{|c|l|l|}
\hline Number & Component & Reference \\
\hline 6 & $\begin{array}{l}\text { Outline corrective actions to } \\
\text { increase service list as necessary. }\end{array}$ & $\begin{array}{l}\text { TM 3-34.48-2 (2016, pg. 4-7, para. } \\
4-29)\end{array}$ \\
\hline 10 & Design vertical slopes. & TM 3-34.48-2 (2016, para. 2-65) \\
\hline 11 & Design transverse slopes. & TM 3-34.48-2 (2016, para. 2-71). \\
\hline 12 & Design taxiways and aprons. & $\begin{array}{l}\text { TM 3-34.48-2 (2016, pg. 2-28, } \\
\text { paras. 2-76 and 2-81) }\end{array}$ \\
\hline 13 & $\begin{array}{l}\text { Design required drainage } \\
\text { structures. }\end{array}$ & $\begin{array}{l}\text { TM 3-34.48-2 (2016, pg. 4-44, } \\
\text { para. 4-107) }\end{array}$ \\
\hline 14 & $\begin{array}{l}\text { Select visual and nonvisual aids to } \\
\text { navigation. }\end{array}$ & $\begin{array}{l}\text { TM 3-34.48-2 (2016, pg. 3-1, para. } \\
3-5)\end{array}$ \\
\hline 16 & Design logistical support facilities. & $\begin{array}{l}\text { TM 3-34.48-2 (2016, pg. 2-9, para. } \\
2-24)\end{array}$ \\
\hline & Design aircraft protection facilities. & $\begin{array}{l}\text { TM 3-34.48-2 (2016, pg. 2-9, para. } \\
2-24)\end{array}$ \\
\hline
\end{tabular}




\section{Summary}

In summary, this document provides the technical data required to code and implement the TASS module for the ENSITE tool. Requirements are focused around the 8 (of 16 total) design components outlined in TM 334.48-2 (2016) that relate to expendient aircraft.

Not all criteria apply because expedient design criteria differ from more permanent airfield design criteria by focusing solely on the runway and not on any supporting infrastructure or surfaces. Additionally, because ENSITE/TASS is a remote planning tool, it does not support some data that require data from a non-remote field survey. For these reasons, this document provides technical guidance for only 8 of the 16 design components, as outlined section 2.1. 


\section{References}

Anderton, Gary L, Ernest S. Berney IV, Travis A. Mann, J. Kent Newman, E. Alex Baylot, Daniel K. Miller, and Quint Mason. 2008. "Joint Rapid Airfield Construction (JRAC) 2007 Technology Demonstration.” Vicksburg, MS: Engineer Research and Development Center-Geotechnical and Structures Laboratory.

ARA, Inc.-ERES Division. 2001. "Correlation of CBR Values with Soil Index Properties." Appendix CC-1 in Guide for Mechanistic-Empirical Design of New and Rehabilitated Pavement Structures. Champaign, IL: Applied Research Associates, Inc. Publication written for and funded by National Cooperative Highway Research Program (NCHRP) of Transportation Research Board, National Research Council.

ETL 09-6. 2009. "C-130 and C-17 Landing Zone (LZ) Dimensional, Marking, and Lighting Criteria." FOUO. (To obtain the document, contact the publications manager at the Whole Building Design Guide via link on this webpage: https://www.wbdg.org/ffc/af-afcec/engineering-technical-letters-afetl/etl-o9-6.)

ETL 97-9. 1997. "Criteria and Guidance for C-17 Contingency and Training Operations on Semi-Prepared Airfields.” Tyndall AFB, FL: Headquarters, Air Force Civil Engineer Support Agengcy (AFCESA)/CES. https://www.wbdg.org/FFC/AF/AFETL/etl_97_9.pdf.

FM 5-430-00-2. 1994. "Planning and Design of Roads, Airfields, and Heliports in the Theater of Operations-Airfield and Heliport Design." Washington, DC: Headquarters, Department of the Army.

TM 3-34.43. 2015. "Materials Testing." Washington, DC: Headquarters, Department of the Army.

TM 3-34.48-2. 2016. Theater of Operations: Roads, Airfields, and Heliports--Airfield and Helifport Design. Washington, DC: Headquarters, Department of the Army.

TM 3-34.64. 2012. "Military Soils Engineering." (Supersedes FM 5-410). Washington, DC: Headquarters, Department of the Army.

UFC 3-260-02. 2001. "Pavement Design for Airfields." Washington, DC: Department of Defense. 


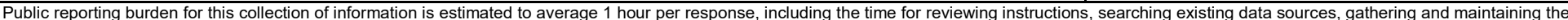

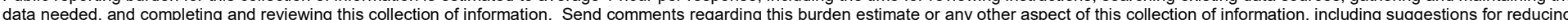

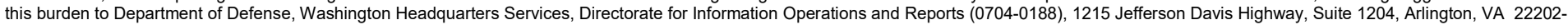

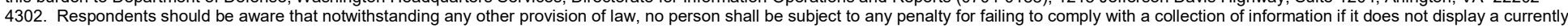
valid OMB control number. PLEASE DO NOT RETURN YOUR FORM TO THE ABOVE ADDRESS.

\begin{tabular}{l|ll}
\hline \multicolumn{1}{|c|}{$\begin{array}{c}\text { 1. REPORT DATE (DD-MM-YYYY) } \\
\text { September } 2018\end{array}$} & 2. REPORT TYPE & Final \\
\hline 4. TITLE AND SUBTITLE & &
\end{tabular}

\section{TITLE AND SUBTITLE} Final

Parameters Used in the Tactical Airfield Siting Selection Module for ENSITE

Joseph A. Gamez, Patrick J. Guertin, Eric L. Kreiger, and George W. Calfas

5a. CONTRACT NUMBER

5b. GRANT NUMBER

$\mathrm{T} 45$

5d. PROJECT NUMBER

45509

5e. TASK NUMBER

5f. WORK UNIT NUMBER

7. PERFORMING ORGANIZATION NAME(S) AND ADDRESS(ES)

U.S. Army Engineer Research and Development Center (ERDC)

Construction Engineering Research Laboratory (CERL)

PO Box 9005

Champaign, IL 61826-9005

\section{SPONSORING / MONITORING AGENCY NAME(S) AND ADDRESS(ES)}

Assistant Secretary of the Army for Acquisition, Logistics and Technology

103 Army Pentagon

Washington, DC 20314-1000 NUMBER

ERDC/CERL SR-18-27

(ASA(ALT)) NUMBER(S)

\section{DISTRIBUTION / AVAILABILITY STATEMENT}

Approved for public release. Distribution is unlimited.

\section{SUPPLEMENTARY NOTES}

\section{ABSTRACT}

The Army must have an ability to rapidly plan and locate engineering sites, such as soldier base camps or airfields, for supporting maximum combat effectiveness of deployed forces. By defining mission-specific site requirements prior to force deployment and facility locations and construction, Army commanders and planners are able to optimize various siting and design decisions. This report documents the technical and doctrinal parameters used to develop the Tactical Airport Site Selection (TASS) module in the Engineer Site Identification for the Tactical Environment (ENSITE) computer planning tool. ENSITE/TASS is a remote planning tool designed for field-expedient use and a very specific set of design criteria. This report contains the rationale for why the ENSITE/TASS development process made certain assumptions, how it calculated certain quantities, and which sources of data it incorporated.

\section{SUBJECT TERMS}

Military bases-Location, Air bases-Location, Data curation, Geospatial data, Computer programs, Military planning, Engineer Site Identification for the Tactical Environment (ENSITE)

\begin{tabular}{|c|c|c|}
\hline \multicolumn{3}{|c|}{ 16. SECURITY CLASSIFICATION OF: } \\
\hline $\begin{array}{l}\text { a. REPORT } \\
\text { Unclassified }\end{array}$ & $\begin{array}{l}\text { b. ABSTRACT } \\
\text { Unclassified }\end{array}$ & $\begin{array}{l}\text { c. THIS PAGE } \\
\text { Unclassified }\end{array}$ \\
\hline
\end{tabular}

\begin{tabular}{|c|c|}
\hline $\begin{array}{c}\text { 17. LIMITATION } \\
\text { OF ABSTRACT }\end{array}$ & $\begin{array}{c}\text { 18. NUMBER } \\
\text { OF PAGES }\end{array}$ \\
& 33 \\
\end{tabular}

\section{DATES COVERED (From - To)}
5c. PROGRAM ELEMENT NUMBER
8. PERFORMING ORGANIZATION REPORT
10. SPONSOR/MONITOR'S ACRONYM(S
11. SPONSOR/MONITOR'S REPORT

